\title{
Myb-Related Protein B
}

National Cancer Institute

\section{Source}

National Cancer Institute. Myb-Related Protein B. NCI Thesaurus. Code C17401.

Myb-related protein B (700 aa, $79 \mathrm{kDa}$ ) is encoded by the human MYBL2 gene. This protein is involved in the regulation of gene expression, cell proliferation and cell differentiation. 